\title{
ЛОГОСИ У ВЧЕННІ СВ. МАКСИМА ІСПОВІДНИКА ЯК ЕПІСТЕМОЛОГІЧНІ ПРИНЦИПИ СТОСУНКУ БОГА З ЛЮДИНОЮ І СВІТОМ
}

Спілкування людини з Богом, особистий стосунок любові між Богом та його творінням, наше пізнання Бога - це одвічна ціль християнського духовного життя, апогеєм якого є максимальне уподібнення людини до Бога, набування за благодаттю тих якостей, які притаманні Богові за природою, тобто обоження. Яким чином відбувається це спілкування? Завдяки чому ми маємо доступ до нього? В який спосіб ми можемо наблизитися до Бога, який у своїй суті є трансцендентним і абсолютно непізнаваним? Адже, як відомо, між несотвореним і сотвореним буттям лежить онтологічна прірва, яку сотворене буття ніяк не в силі подолати. Очевидно, що саме Бог робить до нас перший крок, ініціює цей стосунок, сходить до нас, аби ми могли піднятися. I власне тому ми можемо споглядати Бога, тому можемо хоч обмежено, відповідно до наших можливостей, пізнати Його, що Він перший нам себе об'явив і продовжує об'являти.

Питання меж богопізнання $\mathrm{i}$ середників, завдяки яким воно відбувається, віддавна цікавило християнських мислителів як Сходу, так і Заходу. Проте в цій статті ми спрямуємо свій погляд на Схід, а саме на велетня думки, якого можна вважати одним із найвідоміших систематизаторів східнохристиянського вчення: св. Максима Ісповідника. Особливу увагу в цій статті ми звернемо на поняття, яке є ключовим для Максима: це його концепція логосів.

У цій статті ми розглянемо, яким чином логоси слугують засобами вираження Бога назовні через творення світу та діяльність у ньому. Адже, як твердить східнохристиянська традиція, божественну сутність неможливо пізнати, отож мусить бути якась діяльність Бога, щось, завдяки чому Бог об'являється людині та ініціює стосунок, щось, що може бути осягнене розумом як принцип сотвореного світу. Ми поглянемо на те, яку роль логоси як одвічні задуми Божі стосовно творіння відіграють

${ }^{*}$ Mariia Hupalo STB - Assistant at Theology Department, Faculty of Philosophy and Theology, Ukrainian Catholic University; Lviv; Марія Гупало - асистент кафедри богослов'я Філософсько-богословського факультету Українського Католицького Університету (Львів); е-mail: mhupalo@ucu.edu.ua. 
у нашому стосунку з Богом та яким чином Бог через них приводить до спасіння увесь світ ${ }^{1}$. Завдяки ним Бог творить речі та підтримує їх в існуванні, а також об'являє себе назовні, для онтологічно іншого буття, тобто для нас. Відповідно, за допомогою логосів ми можемо пізнавати Бога через Його діяльність у світі, споглядати Його творіння, а згодом - $\mathrm{i}$ Його самого, однак не безпосередньо Його сутність, а те, за допомогою чого Він виражає Себе як Особу (точніше, спільноту Осіб) у доступний для нашого сприйняття спосіб.

Після того, як ми розглянемо основні засади богопізнання у вченні Максима, ми перейдемо до розгляду, як відбувається пізнавальна діяльність людини, яка повинна мати своїм наслідком знання Бога. Це природне споглядання, тобто фvбıкүे $\theta \varepsilon \omega \rho^{\prime} \alpha$, яке супроводжується зростом у чеснотах. Набування чеснот, які є онтологічними характеристиками Бога, Його властивостями, тісно пов'язане із богопізнанням: одне $є$ передумовою іншого, і навпаки².

Врешті, ми розглянемо питання участі людини у божественному житті у контексті вчення Максима про логоси. Через логоси людина може брати участь у Бозі, бути сопричасною Богові, залишаючись при цьому сотворінням. Ця участь $\left(\mu \varepsilon \dot{\varepsilon} \varepsilon \xi \xi_{1 \varsigma}\right) \in$ невід’ємною складовою нашого стосунку з Богом і $є$ логічним продовженням тої участі, яку беруть у божественному житті всі сотворені речі, завдяки чому Бог підтримує ïх в існуванні. Участь, яка приводить нас до обоження, є онтологічною i не носить характер чисто пізнання. Вона є радше персональною, особистою зустріччю з Богом, яка перемінюе спосіб нашого буття,

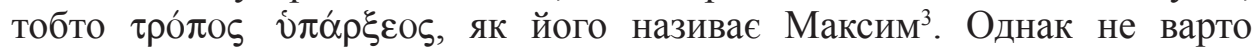
забувати, що цей персональний вимір участі в Бозі аж ніяк не суперечить епістемологічному їі виміру. Навпаки, вони невіддільні один від одного. Пізнання тут слід розуміти не як відсторонене дослідження певного об'єкту, а як міжособистісну взаємодію, вихід поза межі себе і єднання, яке в остаточному підсумку є понад пізнання, перевершує наш розум і $є$ в своїй суті апофатичним.

1. Логоси як маніфестація Бога ad extra. Згідно з переконанням Отців Церкви, зокрема Максима, немає жодного сущого, а радше жодної сутності, яка б не мала власної енергії самовираження. Енергія сутності - це немовби випромінювання, завдяки яким вона пізнавана і взагалі

${ }^{1}$ Пop. E.D. Perl, Methexis: Creation, incarnation, deification in Saint Maximus Confessor, New Haven 1991, 112.

${ }^{2}$ Пop. Maximus Confessor, Ambiguorum liber 10, ed. N. Constas: Maximos the Confessor, On Difficulties in the Church Fathers: The Ambigua, I, Cambridge 2014, 158. Максим говорить, що споглядання навіть передує та $є$ запорукою чесноти, яку аскетична практика та стриманість лише виявляють назовні.

${ }^{3}$ Пop. ibidem 7, ed. Constas, I, c. 128-132. 
може існувати. Адже для кожної сутності притаманно практикувати те, що іiі характеризує, тобто практикувати свої природні здатності

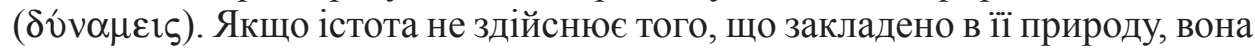
не актуалізує, не виражає себе 4 у тому властивому значенні, 3 якого ми бачимо, що це саме ця річ чи істота, а не яка-небудь інша:

“Неможливо знати божественну чи людську природу, навіть знати, що вона існує чи те, що вона відрізняється від іншої природи, окрім як через

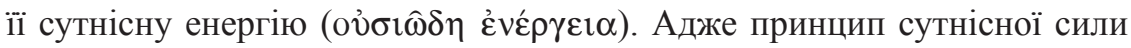
якоїсь речі $\epsilon$, строго кажучи, визначенням цієї речі - якщо зникає ця сила, суб'єкт їі зникає разом із нею"5.

Цей принцип застосовний не лише до сотворених сущих, але й до Бога. Про це говорили вже Атанасій Олександрійський та Каппадокійські Отці, сперечаючись із аріанізмом. Властиво, одним із аргументів Атанасія проти аріан полягав у тому, що між Отцем і Сином не може бути посередництва через енергію, тобто діяльність сутності. Ця діяльність може слугувати середником у спілкуванні Бога зі світом, який є онтологічно іншим, але аж ніяк не між єдиносущними Особами Трійці, тому енергія, дія Трійці мусить бути єдиною ${ }^{6}$. На противагу до Свномія, який нахабно вважав, що людина може пізнати Бога в сутності завдяки одному лише

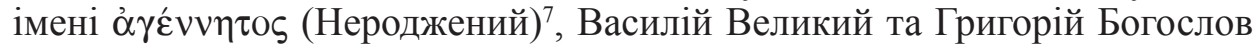
наголошували на тому, що пізнавальні можливості людини обмежені, більше того, божественна сутність безмежно трансцендентна і неподібна на творіння, тому що́ б ми не сказали про нього, яку б аналогію не привели, цього ніколи не буде достатньо, і це буде лише атрибутами божественної природи, а не вона сама ${ }^{8}$.

${ }^{4}$ Це уявлення походить із арістотелівської філософії, адже саме Арістотель уперше

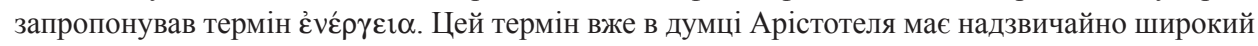
спектр значень: актуальність, діяльність, акт, сповненість, досягнення мети. Поняття

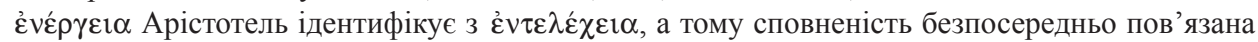
3 активністю, що $є$ використанням своїх можливостей на противагу до лише володіння ними, пор. D. Bradshaw, Aristotle East and West: Metaphysics and the Division of Christendom, New York 2004, 14. Ця діяльність передовсім полягає у використанні своїх можливостей

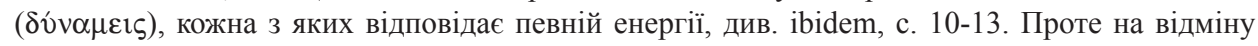
від сотворених буттів Бог $є$ абсолютним сповненням, актуальністю і не потребує рухатися (кıvєiv) від потенції до актуальності, бо сам є реалізацією всіх потенцій, див. ibidem, c. 24.

${ }^{5}$ Maximus Confessor, Opuscula theologica et polemica, PG 91, 201A-B, переклад мій.

${ }^{6}$ Пop. Athanasius Alexandrinus, Ad Serapionem 1, 31, PG 26, 600C - 601A; Basilius Magnus, Contra Eunomium III.4, PG 29, 661B - 664C.

${ }^{7}$ Пор. Eunomius, Liber Apologeticus 8. Див. також G.A. Keith, Our Knowledge of God, “Tyndale Bulletin" 41 (1990) fasc. 1, 73.

${ }^{8}$ Пор. Gregorius Nazianzenus, Oratio 38, 7, PG 36, 317В: “Божественна природа є немовби море сутності, невизначене і таке, яке безкінечно простягається за межі всякого поняття часу і природи", переклад мій. 
Якщо згадаємо, що вчення про логоси у Максима Ісповідника було спрямоване проти хибної концепції божественної простоти, яка ставила іiі в діалектичну напругу супроти множинності світу ${ }^{9}$, то "незлитна і нероздільна" множинність, яка характеризує логоси, тільки і може слугувати інструментом для розуміння людиною Бога. Якщо не приймати в Бозі нічого, окрім простоти, ми робимо проблематичним, суперечливим за своєю суттю будь-який вихід Бога ad extra. Тільки прийнявши “розрізнення, що не розділяє" хоча б частково пізнаваний і що між Ним і світом $є$ якийсь контакт, i цей контакт є онтологічним. В іншому випадку неможливо ствердити, чому світ існує, а також говорити про будь-яке богопізнання. Логоси займають «проміжну позицію між Богом та світом, причому цей «простір», якщо можна так висловитися, є безконечним, 3 огляду на об'єктивну безконечність Бога"11. Вони передіснують в умі Творця одвічно, а тому перевершують усе суще іє зразками для сотворених речей.

Саме про неможливість іншого епістемологічного підходу до Бога, окрім як через логоси, говорить Максим у 22 Амбігві. Якщо енергія $є$ самовираженням Бога назовні, то кожна енергія об'являє Бога у конкретний, властивий їй, спосіб, як конкретну Божу волю, отож логос як сутнісний принцип речі слугує для ідентифікації конкретної енергії ${ }^{12}$.

“Отож, коли ум сприймає логоси в речах у природний спосіб, споглядаючи енергії Божі в безмежності цих логосів, він виявляє, що $є$ багато, а точніше, безмежна кількість різновидів божественних енергій, які він сприймає. I, найімовірніше, виявить, що його здатність $€$ мізерною, а метод пошуку знання - непридатним перед Тим, Хто $\epsilon$ єдино Правдивим; нездатним зрозуміти, як Бог, що по правді не $\epsilon$ жодною із речей, що існують, і водночас, властиво кажучи, є усім і понад усе, $є$ в кожному логосі кожної речі окремо й у всіх логосах усіх речей, взятих разом. Якщо, отже, правдиво казати, що кожна божественна енергія виявляє через себе Бога, цілого і нероздільного, [як присутнього] у кожному [творінні], у згоді з логосом його власного конкретного існування - в такому випадку, хто здатний зрозуміти і точно виразити, як Бог у Своїй повноті $є$ неподілено і нероздільно присутній у всіх речах разом і в кожному сущому у конкретний спосіб, не будучи підвладним ані розмаїттю розрізнень відповідно до безмежних варіацій

${ }^{9}$ Ідеться про вчення Орігена про передіснування душ, передумовою якого було уявлення про абсолютну простоту Бога, якій множинність світу протиставляється як щось негативне, що виникло через певне відпадіння духовних сутностей від цієї простоти. Пор. Origenes, $\mathrm{De}$ principiis I 1, 6, PG 11, 124C - 126C; I 2, 10, PG 11, 141B; I 4, 2, PG 11, 156C.

${ }^{10}$ Пop. Farrell, Free Choice in St Maximus the Confessor, South Canan 1989, 137.

${ }^{11}$ Пop. Maximus Confessor, Ambiguorum liber 7, ed. Constas, I, c. 90-92.

${ }^{12}$ Пop. Loudovikos, A Eucharistic Ontology: Maximus the Confessor's Eschatological Ontology of Being as Dialogical Reciprocity, transl. E. Theokritoff, Brookline 2010, 100 
в речах, у яких Він є присутній, ані не будучи втисненим в індивідуальне існування кожної з них; ані не втискає Він різницю між речами в одну монолітну цілісність усіх речей, але Він справді є всім у всьому, ніколи не покидаючи Свою нероздільну простоту?"13.

Логоси є вираженням одночасної трансцендентності та іманентності Бога, а спосіб їхнього буття виявляє напругу між одиничністю і простотою Бога та множинністю та різноманіттям сотвореного світу. Логос є центром, у якому сходяться усі логоси. Максим використовує образ кола та його радіусів, який добре відображає водночас єдність, тотожність логосів та їхнє розмежування:

“Один Логос є багатьма логосами і багато є Одним. Завдяки творчому та підтримуючому ісходженню Одного до індивідуального буття, як годиться божественній благості, Сдине є багатьма. Завдяки ж зворотному, ведучому і промислительному поверненню багатьох до Єдиного, як до всемогутньої точки початку, або до центру кола, що наперед містить початки радіусів, що з нього походять - оскільки Єдине об'єднує усе разом, остільки багато є Сдиним. Ми, отже, $є$ і називаємося «частинками Бога» через логоси нашого буття, які вічно існують у Бозі”14.

Завдяки цьому Логос ${ }^{15}$ метафізично присутній у кожному сотвореному бутті $^{16}$. У Логосі як центрі логоси існують неподільно ( $\left.\alpha \delta 1 \alpha \iota \eta \tau \hat{\omega} \varsigma\right)$, але

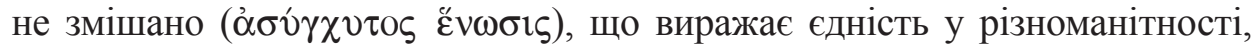
що є ключовою характеристикою Максимової системи. Можна помітити, що Максим застосовує халкедонську риторику. Вірність Халкедону теж $\epsilon$ властивою ознакою його христоцентричного вчення, оскільки Христос як центр вселенної та Той, що все об'єднує, стає образом, на який взорується уся світобудова. Тому як Христос здійснив іпостасне з'єднання двох природ, так і два полюси буття з'єднуються за принципом нероздільності та незлитності. Через логос річ твориться і бере участь у Бозі як Житті, Бутті та Благу, і не в «частинці» життя, буття і блага, а в повноті. 3 іншого боку, ця участь є обмежена природою речі, яка визначає іï сутність, а отже, i міру участі їі в Бозі. Вони є тими середниками, за допомогою яких все суще отримує власне буття і черпає свій зміст із божественного життя. Адже лише Бог є “буттям у властивому сенсі”, тобто тим, хто має його не від когось іншого, а сам від себе. Творіння, яке є буттям лише "за

${ }^{13}$ Maximus Confessor, Ambiguorum liber 22, ed. Constas, I, c. 450, переклад мій

${ }^{14} \mathrm{Ibidem} 7$, ed. Constas, I, c. 102, переклад мій.

${ }^{15}$ Логос (із великої літери) означає Другу Особу Божу, Слово, яке містить у Собі і мислить логоси; натомість логос (із малої літери) позначає сенси, які є підгрунтям для сотворених речей та середником їх спілкування з Богом.

16 Як вважає Т. Толлефсен (Christocentric Cosmology of St. Maximus the Confessor, New York 2008, 68), цей образ Максим запозичив у Діонісія, а той, у свою чергу, побачив іїі у творах неоплатоніків, адже Плотін частим вжитком «канонізував» цей образ для неоплатонізму. 


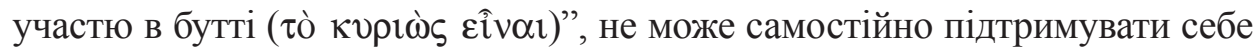

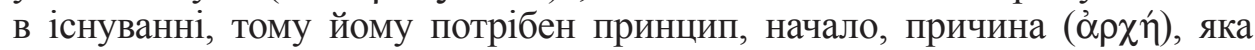
визначає, чим $\epsilon$ та чи інша річ і в який спосіб вона бере участь у Бозі ${ }^{17}$. Крім того, принцип, згідно з яким річ твориться і визначається ${ }^{18}, \epsilon$ також принципом ії̈ нерозривної участі в Бозі, який є джерелом буття, і водночас принципом іії досконалості, тобто обоження ${ }^{19}$. Логоси становлять «незмінну законність», невідкличну ідентичність та одночасну єдність усіх речей, а також виявляють божественні провидіння і суд ${ }^{20}$. Логоси «імплантуються» в творіння, надаючи йому зміст, відмінність від інших творінь, природу та ідентичність ${ }^{21}$. Таким чином Бог, само-розподіляючись у творінні, обдаровуючи його своїм життям, здійснює свою ікономію. Завдяки цьому ми, споглядаючи природу, можемо пізнавати, ким є Бог і яким Він $\epsilon$.

2. Фvбıкท̀ $\theta \varepsilon \omega \rho i ́ \alpha$ як пізнання Бога через творіння. Перейдімо тепер до докладнішого розгляду того, яким чином людина у своєму духовному прогресі занурюється у пізнання божественної мудрості і благості через споглядання Його діл, які Його характеризують. Яким чином логоси, за допомогою яких Бог управляє світом та об'являється, можуть називатися божественними іменами? Як вони співвідносяться з енергіями?

Особа, яка споглядає сотворений світ, через віру і власний духовний зір виявляє у кожній сотвореній речіії логос, задум, який Господь має стосовно цієї речі, i, відповідно, іiї призначення, і ці логоси підносять людину до споглядання невидимого. Чому логоси сотворених речей мають таку властивість - виявляти Бога? Максимові властиве таке бачення світу, яке ототожнює його $з$ тілом Христа, вселенською «природною» Церквою, тому кожен ії̈ вияв, тобто кожна істота, кожен камінчик, кожен порух стає для нас своєрідною містагогією, введенням у таїнство: “свята Церква Божа - це

${ }^{17}$ Пор. Perl, Methexis, c. 116.

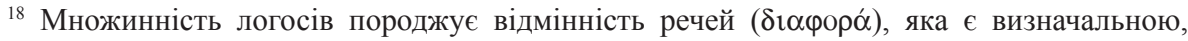

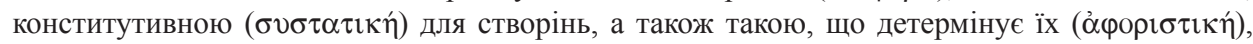
конкретизує їхню суть. Див. Maximus Confessor, Opuscula theologica et polemica 21, PG 91, 249C; idem, Ambiguorum liber 67, ed. Constas, II, c. 294. Пop. J. Zizioulas, Communion and Otherness: Further Studies in Personhood and the Church, London 2006, 22; L. Thunberg, Microcosm and Mediator: The Theological Anthropology of St Maximus the Confessor, пер. A.M. Allchin, Chicago 1995, 51. Адже все, що сотворене і мало початок, існує у певний спосіб ( $\pi \hat{\omega} \varsigma$ عîvol), тобто кожна річ має свою ідентичність і цим відрізняється від інших речей. Бог у свою чергу

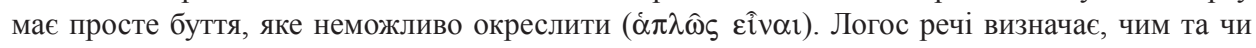
інша річ відрізняється від всіх інших, а також до якої цілі прямує.

${ }^{19}$ Пop. Maximus Confessor, Ambiguorum liber 7, ed. Constas, I, c. 94; H.U. von Balthasar, Cosmic Liturgy: The Universe According to Maximus the Confessor, transl. B.E. Daley, San Francisco 2003, с. 146. Детальніше про цю динаміку поговоримо в контексті її взаємозв'язку із пізнанням Бога.

${ }^{20}$ Пop. Maximus Confessor, Ambiguorum liber 10, ed. Constas, I, c. 202-206; Perl, Methexis, c. 149.

${ }^{21}$ Пop. Perl, Methexis, c. 150. 
образ і зображення цілого світу, що складається із видимих та невидимих сутностей, тому що в ній можна помітити ту саму відмінність і єдність, що існують у ньому"22. Логоси проявляються у чуттєвому світі через певні свої відображення, які людський розум здатний пізнати і виявити ${ }^{23}$. Логос, що є особовим вмістилищем логосів, у якому божественні думки перебувають у неподільній єдності, втілюється у сотвореному світі, у людській природі й через логоси Писання. Він є Той, хто Себе дарує людям, відкриває Себе для нашої участі в Ньому, Податель Життя. Відтак, завдяки цьому Його втіленню у світі, закоріненню у саму буттєвість творіння ми можемо у різний спосіб Його пізнавати та переживати особисту єдність із Ним, із якої природно випливає пізнання ${ }^{24}$. Можна помітити у Максима єдність багатьох реальностей, які переплітаються між собою і взаємно виражають одна одну: це 1) макрокосм чуттєвий та умоглядний; 2) Церква як Тіло Христове; 3) Христос воплочений; 4) Євхаристія; 5) людина як мікрокосм; 6) логоси Писання. Як слова у Писанні, так і чуттєві, матеріальні оболонки є немовби одежами для несотворених логосів, через як втілюється Той, Хто поклав початок цим законам. Однак ці логоси все ж залишаються катафатичним богослов'ям, тоді як нашою ціллю $є$ піднятися понад природне споглядання до самого Логоса. Залишатися лише на рівні природного споглядання тотожне стагнації, а також небезпечному применшенню божества, яке безмежно трансцендує поза межі сотвореного ним світу та принципів його існування, а тому не може ними окреслюватися.

Логос, у якому всі логоси з'єднані, є Учителем ( $\left.\Delta 1 \delta \alpha \sigma \kappa \alpha \lambda \varsigma_{\varsigma}\right)$, який дає нам можливість доторкнутися до Його науки, немов спізнати Його Тіла i Крові, i через споглядання умоглядних принципів сотвореного буття ми відкриваємо причину всякого буття у світі, а також промисел і суд Божий. "Всі Божі творіння, що в своїй природі споглядаються нами з відповідним умінням, виявляють нам прихований у них логос і в кожному творінні Божому відкривають своє призначення"25. Тому через споглядання логосів ми підносимо наш ум до Бога, адже через пізнання співвідношення між сотвореними речами ми немовби «зчитуємо» присутність божественного Логосу. Так само, як логоси Писання відкривають нам правду про Бога, і логоси всього, що існує, є немовби “космічним Писанням", через яке Бог пізнається. Той, хто споглядає світ не чуттєвим, а духовним поглядом, пізнає символи, які відкривають божественні логоси i таким чином віднаходить у логосах Бога, сходячи від пізнання величі істот до величі їх Причини ${ }^{26}$. Логоси-випромінення Логоса $є$ середниками Божого сходження

\footnotetext{
${ }^{22}$ Maximus Confessor, Mystagogia II, PG 91, 668C, переклад мій.

${ }^{23}$ Пop. ibidem II, PG 91, 689C-D.

${ }^{24}$ Пop. idem, Ambiguorum liber 10, ed. Constas, I, c. 196.

${ }^{25}$ Idem, Quaestiones ad Thalassium 13, PG 90, 296A, переклад мій.

${ }^{26}$ Пop. ibidem 50, PG 372B.
} 
до нас, катабазису, а наше споглядання цих реальностей - нашого висхідного руху до Бога (анабазису). Бог є об'єднавчим началом світу, який уніфікує всю його множинність в одне ціле. Бог як Причина є центром, в якому об'єднуються всі Його прояви. Тому, вглядуючись у сотворений світ, пронизаний божественною присутністю, ми також пізнаємо певні характеристики Бога. Також вглядуючись у себе саму, пізнаючи свою природу, людина, немов у дзеркалі, бачить відображення Божого образу.

Максим вказує на безпосередній зв'язок природного споглядання із переображенням, яке слідує із нього, і ми від споглядання Логоса через логоси перейдемо до безпосереднього стосунку з Ним ${ }^{27}$. Переображення Максим пов'язує зі станом спокою, зупинки руху, в якому ми досягнули цілі наших прагнень і нашої любові - Господа. Цей лейтмотив переплітається 3 тематикою природного споглядання ${ }^{28}$. Останнє, за Максимом, має п'ять різновидів, за п'ятьма властивостями сущого: сутність, рух, розрізнення, змішання і позиція. Із перших трьох ми черпаємо знання про Бога, як про Творця, Промислителя і Суддю ${ }^{29}$; а завдяки двом останнім людина уподібнюється до Бога, присвоює собі божественні властивості, при цьому залишаючись творінням ${ }^{30}$.

Чеснота для Максима $€$ не просто справою практики, але онтологічною категорією, набуваючи яку, людина уподібнюється і з'єднується з Богом. Поступово людина переходить від споглядання логосів сотвореного буття до самого Творця і Причини всього, і тоді вона приходить до усвідомлення того, що всі логоси є єдиними в Бозі. Така людина з'єднується з духовним світом чеснот і відображає собою незатьмарено самого Логоса ${ }^{31}$.

Фредерік Аквіно зауважує, що чеснота в Максима безпосередньо пов'язана зі здатністю людини до природного, а далі - і до містичного споглядання. Вона $є$ силою, яку Бог вдихнув у порядок речей, тому iii неможливо звести до природного або людського походження - сам Бог

${ }^{27}$ Пop. idem, Ambiguorum liber 10, ed. Constas, I, c. 182-198.

${ }^{28}$ Пop. ibidem, ed. Constas, I, c. 190-194.

29 Логоси провидіння та суду надзвичайно важливі для Максима, адже вони відображають благу дію Бога у світі. Провидіння Боже пов'язане $з$ тим, щоб усе зберігати у тотожності 3 його логосом, а суд не стосується вироку, натомість $є$ тим, що надає певній речі ідентичності, відмежованої від усіх інших ідентичностей. Саме Бог визначає, чим $є$ те чи інше буття, його тропос та іпостась, тобто кожну конкретну річ як вона $є$. Пор. ibidem 10, ed. Constas, I, c. 182. Максим говорить, що «досконалий розум є той, який оглянув загалом усі Його творіння й від Бога отримав усеохопне пізнання про Його провидіння і суду в них». Завдяки творінням людина пізнає, що Бог існує, але не те, чим Він $\epsilon$, оскільки стверджувальне пізнання здійснюється не через сутність, а через промисел, який Бог здійснює у своїх творіннях. Пор. Я. Пеликан, Христианская традиция: история развития вероучения, t. 2: Дух восточного христианства [600-1700], пер. П. Кыржелев, Москва 2007, 32.

${ }^{30}$ Пop. Maximus Confessor, Ambiguorum liber 10, ed. Constas, I, c. 182.

${ }^{31}$ Пop. ibidem, ed. Constas, I, c. 212. 
$\epsilon$ джерелом чеснот ${ }^{32}$. Таким чином, “той, хто бере участь у чеснотах через практикування звички, безперечно бере участь у Бозі, Який є сутністю чеснот"з3. Особистість виявляє чесноту, коли слідує згідно зі своїм логосом, що в Бозі. Чеснотливість людини проявляється у іiі здатності спрямовувати себе до благого буття, а через нього - i до вічного благого буття $^{34}$. Тому для Максима чеснота - це не тільки моральна, а перш за все онтологічна категорія, атрибут Бога ${ }^{35}$.

Крім того, чесноти закладені у саму будову світу, в природу речей через їхній логос. Той, хто вдосконалив свій розум через чесноту, $\epsilon$ здатний справедливо мислити і розрізняти речі й таким чином виявляти істину, споглядаючи певні зразки, які формують наш розум ${ }^{36}$. Коли особа досягає безпристрасності (ỏ $\alpha \dot{\alpha} \theta \varepsilon \iota \alpha)$, вона може відкидати подразники, які відволікатимуть їі від єднання з Богом, бачити речі правдиво й бути відкритою тільки на добро, красу та істину ${ }^{37}$. Таким чином особа звільняється для споглядання божественної реальності i спочатку чітко переходить до споглядання логосів природи, а потім переходить безперешкодно до знання небесних речей ${ }^{38}$. Все це спрямовується до Бога через прагнення і любов, які панують в умі та волі людини. Любов до Бога осіняє людину, наділяючи знанням божественних істин ${ }^{39}$.

Максим Ісповідник також говорить, що розум повинен полишити всі спроби мислення про Бога в рамках логічних категорій та залишити споглядання творінь позаду, бо це заважатиме їй злучитися з Богом у містичному екстазі, який є чистим екзистенційним досвідом, без домішок розумового пізнання. Лише таким чином можна максимально близько підійти до Бога - у виході поза межі себе та мовчанці ${ }^{40}$. Але саме Богу належить першість у поклику до людини, яка на нього відповідає; саме Він ініціює не лише наше творення, але й особистісний зв'язок, у якому ми повинні співдіяти Йому ${ }^{41}$. Ми знаємо Бога у динаміці Його стосунків зі світом та $з$ нами, нам відомо, що Бог є особовим, але те,

${ }^{32}$ Пор. F.D. Aquino, The Synthetic Unity of Virtue and Epistemic Goods in Maximus the Confessor, "Studies in Christian Ethics" 26 (2013) 383.

${ }^{33}$ Maximus Confessor, Ambiguorum liber 7, ed. Constas, I, c. 105, переклад мій.

${ }^{34}$ Пор. idem, Scholia in Librum de divinis nominibus 6, 7-8, PG 4, 325A-B; 7, 3, PG 4, 352A.

${ }^{35}$ Пор. K. Kochańczyk-Bonińska, Ontyczne podstawy przebóstwienia człowieka w nauczaniu św. Maksyma wyznawcy, "Seminare" 34 (2013) 291.

${ }^{36}$ Пop. Aquino, The Synthetic Unity of Virtue and Epistemic Goods, c. 385.

${ }^{37}$ Пop. ibidem, c. 387.

${ }^{38}$ Пop. Maximus Confessor, Capita de caritate 1.85-86, PG 90, 980C.

${ }^{39}$ Mop. Aquino, The Synthetic Unity of Virtue and Epistemic Goods, c. 388.

${ }^{40}$ Пop. Maximus Confessor, Capita theologica et oecumenica II 88, PG 90, 1168A.

${ }^{41}$ Пор. И. Зизиулас, Общение и инаковость: новые очерки о личности и иеркви, пер. М. Толстолуженко - Л. Колкер, Москва 2012, 51. 
яким чином Бог існує у собі, ми ніколи не знатимемо і не можемо навіть частково приблизитися до цієї безмежної тайни ${ }^{42}$.

\section{3. Участь у логосах та енергіях та її зв'язок із богопізнанням.} Поняття участі в духовному вченні Отців Церкви є дуже важливим. Саме через участь людина обожується, і саме в контексті участі в Бозі слід інтерпретувати містичний досвід сприймача божественних енергій. Отож розгляньмо докладніше, у чому полягає цей термін.

Торстейн Толлефсен зауважує, що сам термін, який Отці, а зокрема Максим, використовували для означення сопричастя, має багато варіацій, а отже, і багато відтінків значень ${ }^{43}$. Зокрема, серед них можна виділити

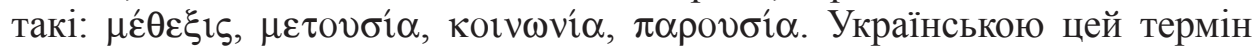
також можна перекласти по-різному: брати участь у (божестві), бути учасником, причасним, сопричасним, сопричастя, участь, спілкування. Отже, потрібно виявити суть того, із чим маємо справу.

Поняття участі, як і багато інших термінів, які засвоїли Отці, зародилося в середовищі неоплатонізму. У Плотіна вчення про участь нижчого буття у вищому пов'язане з його уявленнями про діяльність

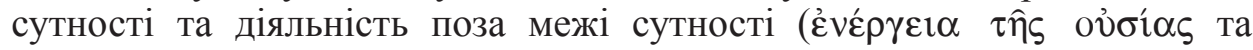

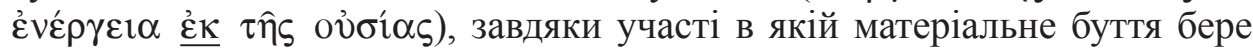
участь у Богові. Це так званий «момент», або середник, участі (par-

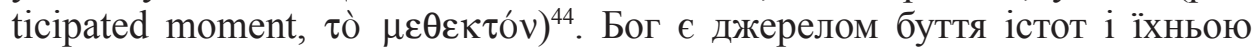
причиною, принципом, i через участь у ній істоти і існують, i обожуються. Бог є принципом сотворення, участі й досконалості творінь, і участь початкова, "недосконала", неодмінно спрямована до досконалої участі, тобто уподібнення до свого Творця ${ }^{45}$. Проте причина сама у собі завжди недоступна для речей, які від неї походять. Бог у Собі недоступний для

42 Як зазначає Д. Станілое (The Experience of God: Orthodox Dogmatic Theology, V/1: Revelation and Knowledge of the Triune God, пер. I. Ionita - R. Barringer, Brookline 1998, 126-127), будь-яке ім'я навіть людської особи є конвенційним, адже кожна особа унікальна, і дати ій ім'я, яке виражало б її буття-в-собі, неможливо. Тим більше це стосується трансцендентного Бога. На його думку, це пов'язано з тим, що особове буття є апріорі і найвищою мірою апофатичне.

43 Докладне пояснення кожного із цих термінів можна знайти у Tollefsen, Christocentric Cosmology of St. Maximus the Confessor, c. 193.

${ }^{44}$ Пop. ibidem, c. 200.

45 Пор. Perl, Methexis, с. 122. Щоправда, він наголошує, що рух від базової до повної участі, хоч і нерозривно пов'язаний із самим поняттям участі в Максима, все одно не може відбуватися за необхідністю. Це живий стосунок між творцем і творінням, стосунок взаємного проникнення і переливання, який однак зберігає ідентичність сотвореної особи. Проте Е. Перл не погоджується із Ж.-М. Гаррігом (Maxime le confesseur: la charité, avenir divin de l'homme, Paris 1976), що цей стосунок - лише «гармонія волі» людської із Божою, не інтенційна, а досконала онтологічна участь. 
участі, адже перевершує всі категорії сотвореної природи й існує поза межами часу ${ }^{46}$.

Логіка, за якою слідує Максим, викладаючи свою науку про участь сотвореного буття в Бозі, незмінно залишається халкедонською. У цьому парадокс Максима: він не обмежує халкедонську формулу лише до христології, а поширює іiі вплив на усю онтологію. Чотири центральні терміни халкедонського віровизнання - незмішано, незмінно, нероздільно, нерозлучно - визначають логіку, якою користується Максим у своєму богословленні, зокрема на тему участі сотвореного буття в Бозі. До прикладу, він говорить, що Бог і світ існують нероздільно, тобто в єдності, але незмішано, адже Бог залишається Богом, i, що дуже важливо, світ залишається світом. Також речі у світі існують розрізнено, незмішано, зберігаючи кожна власну ідентичність, однак не є цілком незалежні одна від одної, а перебувають у спільності через свій стосунок до Бога ${ }^{47}$ та Його перебування ( $\left.\pi \alpha \rho \circ \sigma^{\prime} \alpha\right)$ у речах. Крім того, незмішано і нероздільно існують логоси в умі Бога ${ }^{48}$.

Участь у Бозі згідно з вченням Максима пов'язана із рухом кожного буття, а особливо розумного (яке рухається свобідно), згідно з логосом буття, благого буття та вічного (благого) буття (

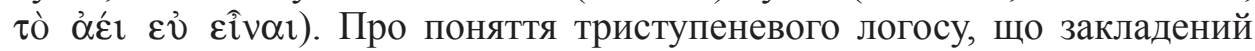
у кожній речі і відрізняється від логосу, що визначає ії сутність, писав, зокрема, Полікарп Шервуд ${ }^{49}$. По-іншому цей потрійний логос можна назвати логосом провидіння ${ }^{50}$. Спасіння $є$ необхідним продовженням творіння, настільки глибоко закоріненим у природу буття, що якщо воно збивається із цього шляху, то йде проти власної суті. Перший етап, буття, $є$ станом відразу після постання. Він $є$ початком руху творіння до актуалізації в Бозі, яка поступово веде його до благого буття, яке для особи реалізується через набуття чеснот, які є атрибутами Бога, тому повноцінний розвиток свого існування через свободу та чесноту є нічим іншим, як "набуванням логосів" 1 . До благого буття кожне створіння стремить, та осягнення цього стану ще не $\epsilon$ остаточною ціллю, адже воно залишається в межах власної природи, а отже, ще не є спасенним. Логоси $€$ передумовами для природного руху створінь до благого буття ${ }^{52}$, а також рухом від образу Божого до подоби за допомогою гномічної волі, адже через них ми беремо участь у бутті, благому бутті та вічному бутті,

\footnotetext{
${ }^{46}$ Пop. Maximus Confessor, Ambiguorum liber 7, ed. Constas, I, c. 104.

${ }^{47}$ Пop. idem, Mystagogia II, PG 91, 668C.

${ }^{48}$ Пop. idem, Ambiguorum liber 7, ed. Constas, I, c. 94.

${ }^{49}$ Mop. Sherwood, The Earlier Ambigua of St Maximus the Confessor and His Refutation of Origenism, Roma 1955, 178.

${ }^{50}$ Пop. Maximus Confessor, Ambiguorum liber 67, ed. Constas, II, c. 292-294.

${ }^{51}$ Пop. ibidem 42, ed. Constas, II, c. 148.

${ }^{52}$ Пop. Farrell, Free Choice in St Maximus the Confessor, c. 138.
} 
які $є$ в Бозі ${ }^{53}$. Перехід від буття до благого буття в розумних створінь залежить від їхнього вибору між добром і злом, тобто рухатися згідно з логосами, чи на противагу їм.

Що ж стається з сотвореним буттям, коли воно, рухаючись за тріадою логосів буття - благого буття - вічного благого буття, досягає обоження? На думку Максима, природа цього створіння, виражена його логосом, залишається незмінною, однак кардинально змінюється тропос буття, або спосіб ії активності у світі ${ }^{54}$. Якщо до того людина актуалізується в рамках власної природи, то тропос, якого їй надає логос вічного благого буття, включає божественну діяльність, яка спрямовує природу до Бога. I що глибше обоження, то більше божественних атрибутів пронизують природу $^{55}$. Коли ж людина досягає остаточного спокою в есхатоні, вона отримує повноту божественної благодаті, божественних властивостей через відмову від чуттєвого та раціонального пізнання, а ії природні здатності трансформуються та стають богоподібними. Вони набувають здатностей, яких вони не могли мати, коли перебували у природному стані як сотворені. Більше того, Максим говорить, що, обожуючись, людина переймає божественний атрибут нескінченності ${ }^{56}$. Це видається неможливим, оскільки вона як сотворена істота мусить мати початок, і водночас, беручи участь у безначальній божественній діяльності, вона 3 необхідністю уподібнюється ій. Бог настільки пронизує людину, що вона стає Богом у всьому, окрім ідентичності власної природи ${ }^{57}$. Це не ототожнення природ, а радше перихореза, спілкування крізь онтологічну прірву між Богом і створінням. Богопізнання - це поступове сходження від найслабшого до все глибшого і глибшого споглядання та єднання з Богом у пориві любові. Це пережиття особливого, надприродного стосунку, який iї обожує, піднімає понад іiі власну природу, робить за благодаттю нетварною і наділяе іiі тими властивостями, які притаманні іiі Творцю та її найбільшій любові ${ }^{58}$.

Цей стосунок також пов'язаний 3 логосами, які стають середниками такого з'єднання, адже з Богом-у-собі з'єднатись неможливо. Саме вони виступають інструментами обоження і богопізнання, яке йде поруч із участю. Коли ми беремо онтологічну участь у Божому житті, через містичний досвід, який є живим стосунком любові ${ }^{59}$, ми набуваємо певних

${ }^{53}$ Пop. Maximus Confessor, Ambiguorum liber 7, ed. Constas, I, c. 106.

${ }^{54}$ Пop. D.S. Yeago, Jesus of Nazareth and Cosmic Redemption: The Relevance of St. Maximus the Confessor, "Modern Theology" 12 (1996) fasc. 2, 185.

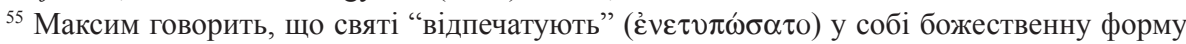
через чесноти. Пор. Maximus Confessor, Ambiguorum liber 10, ed. Constas, I, c. 154-156; Perl, Methexis, c. 129.

${ }^{56}$ Пop. Maximus Confessor, Ambiguorum liber 10, ed. Constas, I, c. 224.

${ }^{57}$ Пop. ibidem 42, ed. Constas, II, c. 108.

${ }^{58}$ Пop. idem, Scholia in Librum de divinis nominibus 4, 4, PG 4, 245C.

${ }^{59}$ Пор. idem, Diversa capita ad theologiam et oeconomiam spectantia V 74, PG 90, 1380. Див. 
знань про Бога. Знову ж таки, це знання про Бога не є статичним набором догм, а динамічним обміном енергіями, міжособовим стосунком par excellence, через який Бог відкривається нам як Особа, як Діяч.

Максим говорить, що логоси розподіляються на кожного учасника ( залежить від гідності сприймача ${ }^{60}$. Вони є безмежні, як сам Бог, тому участь людини в них, якою б не була глибокою, ніколи не вичерпає їх. У своій Сьомій Амбігвi, яку ми вже не раз цитували, Максим у контексті руху людини до вічного спокою в Бозі, говорить про участь людини в Бозі і навіть те, що вона стає з Ним “одної енергії”'

Стаючи учасником божественного життя, людина переображується, всі іï енергії стають спрямовані до Бога і набувають нових характеристик, притаманних божественній природі. Всі ці асперкти Максим приписує стану людини, який він називає спокоєм, тобто моментом сповнення людини, правдивого i нерозлучного з'єднання людини 3 Богом. Відбувається взаємне проникнення Бога і людини, що приймає Його благодать, i саме про цей момент сказано: живу вже не я, а живе в мені Христос (Гал 2,20$)$. Це взаємне проникнення і зоветься участю:“Чеснота й усяке наше наслідування Бога робить його власника достойним єдності з Богом, благодаттю ж досягається саме несказанне єднання, через яке «всецілий Бог переходить ( $\left.\pi \varepsilon \rho \imath \chi \omega \varepsilon^{\prime}\right)$ у всецілих гідних"б2. Цей зв'язок $\epsilon$ надзвичайно інтимний і проникає в найглибші закутки людського єства, яке приймає цю енергію, яка є Богом у повноті - безмежною, - тою мірою, наскільки людина здатна ії засвоїти. Ця зустріч є завжди особовоюб ${ }^{63}$

$$
* * *
$$

Вивчаючи основні тексти Максима Ісповідника, що стосуються енергії, тобто діяльності божественної сутності, ми виявили, що для неї характерно: це вияв сутності назовні, яким володіє не лише Бог, але й кожна сотворена істота, адже сутність не може існувати і водночас не виявляти себе жодними діями, жодними властивостями. Але оскільки Бог $є$ не просто сутністю, а й Особою, Сущим (точніше, спільнотою Осіб), то його діяльність назовні проявляється не у внутрітроїчних стосунках, а в творенні онтологічно інакшого буття, обмеженого часом і своєю власною ідентичністю і відмінністю від інших речей. Така творча

T. Mada, Love and Knowledge in Patristic Tradition, "International Journal of Orthodox Theology" 5 (2014) fasc. 1, 201.

${ }^{60}$ Пop. Maximus Confessor, Diversa capita ad theologiam et oeconomiam spectantia II 31, PG 90, 1232.

${ }^{61}$ Idem, Ambiguorum liber 7, ed. Constas, I, c. 103.

${ }^{62}$ Пop. ibidem 20, ed. Constas, I, c. 414.

${ }^{63}$ Пop. Mada, Love and Knowledge in Patristic Tradition, c. 202. 
діяльність Бога, хоч і співвічна Йому, залежить від волевиявлення Бога творити світ і кожну окрему річ. Бог у жодному разі не вимушений творити світ для того, щоби цим проявляти свою всемогутність ${ }^{64}$. Логоси - вияв волі Бога творити світ і $з$ любові до нього підтримувати його в існуванні та вести до остаточного єднання з Собою, - це енергія, дія Бога, яка Його об'являє і робить Його пізнаваним у тих межах, які дозволяють обмежені можливості нашого сотвореного розуму. Хоч ця енергія є у певному сенсі “нижчою”, “ісходженням” від самої сутності Бога, доступнішою для нашого сприйняття, іiї не слід розуміти як щось інше, ніж Бог. Це той самий Бог у самооб'явленні, Бог у своєму ікономічному виході до нас, Бог як Податель благодаті, яка своєю присутністю виявляє, те, яким Він є.

Більше того, беручи участь у цій благодаті, ми сходимо від самого лише буття в Бозі, тобто факту, що наше існування залежить від Бога, до благого буття, тобто життя в чеснотах і зростання в любові до Бога, що супроводжується все глибшим і глибшим знанням Бога - як через споглядання творіння і пізнання божественних атрибутів, так i через особистий досвід зустрічі. На цьому етапі наше знання Бога і наша подібність до Нього через досконалості, які Йому належать, тобто чесноти, взаємно переплітаються і невіддільні одне від одного, як це зрештою твердить не лише Максим Ісповідник, але й каппадокійські Отці, для яких очищення душі - дзеркала Бога - було необхідною передумовою правдивого богопізнання. I врешті ми переходимо до найвищого ступеня єдності з Богом - вічного благого буття, тобто досвіду переображення, обоження через участь у божественних енергіях, через споглядання Бога вже не через Його атрибути та діяльність у світі, а визнаючи, що Він безконечно перевершує ці атрибути, і що б ми не сказали про Бога ствердно чи заперечно, ми цим ніколи не вичерпаємо Його безмежності.

Тому логоси та енергії завдяки своїй творчій функції є не тільки самовиявом Бога для нас, а й середником для персоналістичної зустрічі з Ним, що перемінює нашу природу. Адже людина нездатна перескочити через власну природу і переобразитися. Вона лише в тому разі може стати богоподібною, коли Господь зробить перший крок і своєю благодаттю наділить нас тим, чим Він володіє за природою.

${ }^{64}$ Так, наприклад, вважав Оріген (De principiis I 2, 10, PG 11, 141B; I 4, 2, PG 11, 156C). Тут проявляється його залежність від неоплатонізму, де божество творить світ не вільно, а за необхідністю. 


\section{LOGOI IN ST. MAXIMUS THE CONFESSOR AS EPISTEMOLOGICAL PRINCIPLES OF RELATIONSHIP BETWEEN GOD AND THE WORLD}

\section{(Summary)}

The knowledge of God and mystical union with Him is intimately connected with the concept of divine transcendence and immanence, His complete hiddenness, unknowability and, at the same time, his participatedness, grace and economical coming-out toward creature. Interrelatedness of these lies at the core of St. Maximus the Confessor's concept of logoi. In this article we focus on how the principles of creation and participation of creature in God function as epistemological principles, according to which man can contemplate God in creatures and then move forward to direct contemplation and deifying participation in God. Special attention is paid to understanding logoi as an activity of God's essence ad extra toward the created otherness. This activity brings existence, sense and identity to created beings and thus can be not only participated, but also known through natural contemplation.

\section{LOGOI W NAUCZANIU ŚW. MAKSYMA WYZNAWCY JAKO ZASADY EPISTEMOLOGICZNE STOSUNKU MIĘDZY BOGIEM A ŚWIATEM}

(Streszczenie)

Poznanie Boga i mistyczne zjednoczenie z Nim jest ściśle związane z koncepcją Bożej transcendencji i imanencji, Jego doskonałej skrytości, niepoznawalności i jednoczesnej otwartości dla naszego uczestnictwa w Nim, łaski i ekonomicznego wyjścia na zewnątrz - do stworzenia. Ich tajemnicza jedność jest rdzeniem doktryny o logoi u św. Maksyma Wyznawcy. Niniejszy artykuł zwraca uwagę na funkcjonowanie zasad stworzenia i uczestnictwa stworzenia w Bogu. Są to zasady epistemologiczne, przez które człowiek może kontemplować Boga w stworzeniach, a potem przejść do bezpośredniej kontemplacji i ubóstwiającego uczestnictwa. Szczególną uwagę zwrócono na pogląd, że logoi są działalnością Bożej esencji w kierunku stworzonej odmienności, ad extra. Działalność Boga udziela istnienia, sensu i tożsamości istotom stworzonym, dlatego człowiek nie tylko może w niej uczestniczyć, ale i poznawać przez kontemplację natury.

Key words: logoi, knowledge of God, epistemological principles, natural contemplation, activity ad extra, participation.

Słowa kluczowe: logoi, poznanie Boga, zasady epistemologiczne, kontemplacja, działalność ad extra, uczęstnictwo.

Ключові слова: логоси, богопізнання, епістемологічні принципи, споглядання, діяльність ad extra, участь. 


\title{
БІБЛІОГРАФІЯ
}

\author{
Джерела
}

Athanasius Alexandrinus, Epistulae ad Serapionem, PG 26, 525-680.

Basilius Magnus, Contra Eunomium, PG 29, 497-774.

Eunomius, Liber Apologeticus, ed. and transl. by R.P. Vaggione, in: Eunomius, The Extant Works, Oxford 1987, 34-74.

Gregorius Nazianzenus, Oratio 38 [In Theophania, sive natalitia salvatoria], PG 36, $312 \mathrm{~A}-333 \mathrm{~A}$.

Maximus Confessor, Ambiguorum liber, ed. N. Constas: Maximos the Confessor, On Difficulties in the Church Fathers: The Ambigua, I-II, Cambridge 2014.

Maximus Confessor, Capita de caritate, PG 90, 959-1082.

MaXimus Confessor, Capita theologica et oecumenica, PG 90, 1084-1176.

MaXimus Confessor, Diversa capita ad theologiam et oeconomiam spectantia, PG 90, $1177-1392$

MaXimus Confessor, Mystagogia, PG 91, 658-721.

Maximus Confessor, Quaestiones ad Thalassium, PG 90, 244-785.

Maximus Confessor, Opuscula theologica et polemica, PG 90, 9-286.

Maximus Confessor, Scholia in Librum de divinis nominibus, PG 4, 185-416.

ORIGENES, De principiis, PG 11, 115-414.

\section{Література}

Aquino F.D., The Synthetic Unity of Virtue and Epistemic Goods in Maximus the Confessor, "Studies in Christian Ethics" 26 (2013) 378-390.

Balthasar H.U. von, Cosmic Liturgy: The Universe According to Maximus the Confessor, transl.. B.E. Daley, San Francisco 2003.

Bradshaw D., Aristotle East and West: Metaphysics and the Division of Christendom, New York 2004.

Farrell J.P., Free Choice in St Maximus the Confessor, South Canan 1989.

Garrigues J.-M., Maxime le confesseur: la charité, avenir divin de l'homme, Paris 1976.

Kегтн G.A., Our Knowledge of God: The Relevance of the Debate Between Eunomius and the Cappadocians, "Tyndale Bulletin" 41 (1990) fasc. 1, 60-88.

KochaŃCZYK-BoniŃsKa K., Ontyczne podstawy przebóstwienia człowieka w nauczaniu św. Maksyma wyznawcy, "Seminare. Poszukiwania naukowe" 34 (2013) 285-294.

Loudovikos N., A Eucharistic Ontology: Maximus the Confessor's Eschatological Ontology of Being as Dialogical Reciprocity, transl. E. Theokritoff, Brookline 2010.

Mada T., Love and Knowledge in Patristic Tradition, "International Journal of Orthodox Theology" 5 (2014) fasc. 1, 189-209.

Perl E.D., Methexis: Creation, incarnation, deification in Saint Maximus Confessor, New Haven 1991.

SHerwood P., The Earlier Ambigua of St Maximus the Confessor and His Refutation of Origenism, Roma 1955.

Staniloae D., The Experience of God: Orthodox Dogmatic Theology, vol. 1: Revelation and Knowledge of the Triune God, пер. I. Ionita - R. Barringer, Brookline 1998.

Thunberg L., Microcosm and Mediator: The Theological Anthropology of St Maximus the Confessor, пер. M. Allchin, Peru 1995.

Tollefsen T., Christocentric Cosmology of St. Maximus the Confessor, New York 2008. 
Yeago D.S., Jesus of Nazareth and Cosmic Redemption: The Relevance of St. Maximus the Confessor, "Modern Theology" 12 (1996) fasc. 2, 163-193.

Zizioulas J., Communion and Otherness: Further Studies in Personhood and the Church, London 2006.

$$
* * *
$$

ЗизиулАс И., Общчение и инаковость: новые очерки о личности и ичеркви, пер. М. Толстолуженко - Л. Колкер, Москва 2012.

ПЕликАН Я., Христианская традиция: история развития вероучения, t. 2: Дух восточного христианства [600-1700], пер. П. Кыржелев, Москва 2007. 
